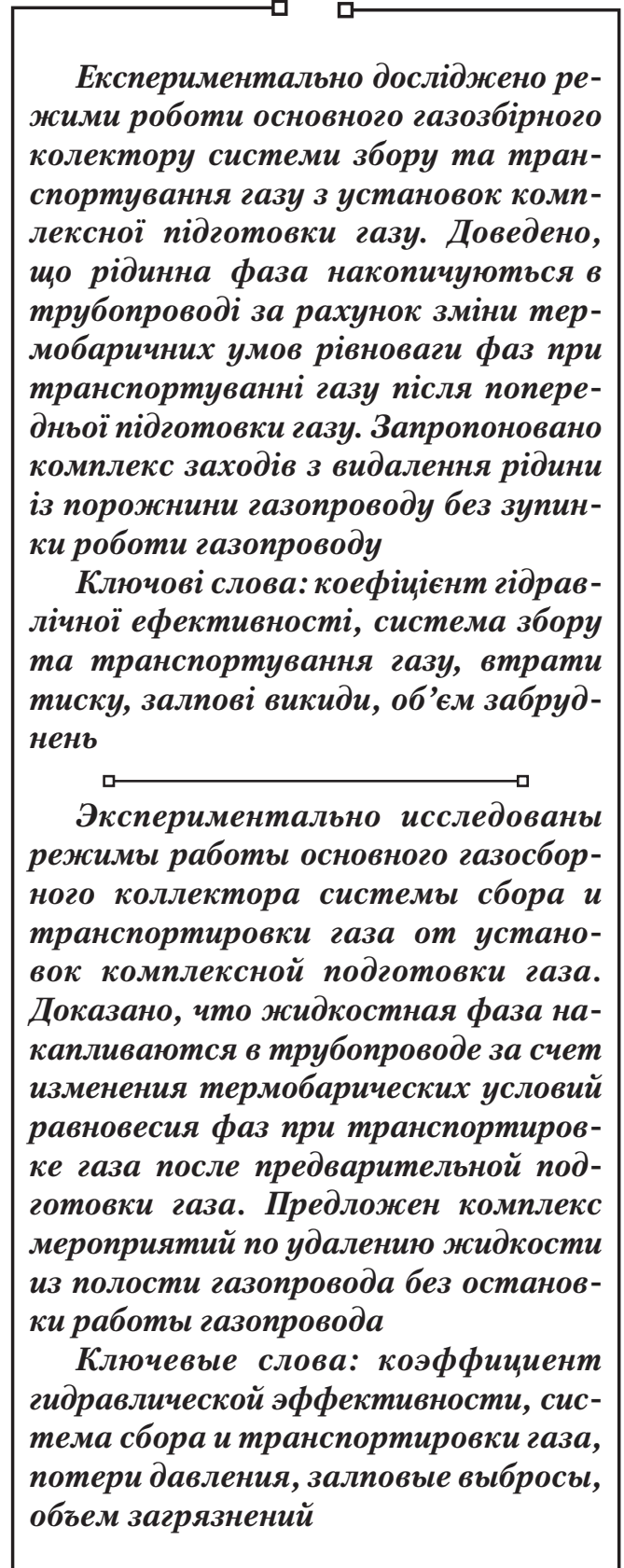

\title{
DEVELOPMENT OF CLEANING METHODS COMPLEX OF INDUSTRIAL GAS PIPELINES BASED ON THE ANALYSIS OF THEIR HYDRAULIC EFFICIENCY
}

\author{
O. Filipchuk \\ Manager \\ Division for the Collection, Preparation \\ and Transport of Hydrocarbons* \\ E-mail: oleksandr.filipchuk@outlook.com \\ V. Grudz
}

Doctor of Technical Sciences, Professor, Head of Department Department for the Construction and Repair of Gas Pipelines and Gas Reservoirs**

E-mail:v.grudz@nung.edu.ua

V. Marushchenko

$\mathrm{Head}^{*}$

E-mail: marushchenko@ugv.com.ua

V. M y n d i u k

$\mathrm{PhD}$, Associate Professor

Department of Energy Management and Technical Diagnostics**

E-mail: tinlaven@gmail.com

M. S a v c h u k

Head of industrial pipelines and electrochemical protection sector*

E-mail: mirosavchuk@gmail.com

*Department of Ground Infrastructure

PJSC «Ukrgazvydobuvannya»

Kudryavska str., 26/28, Kyiv, Ukraine, 04053

**Ivano-Frankivsk National Technical University of Oil and Gas Karpatska str., 15, Ivano-Frankivsk, Ukraine, 76019

\section{Introduction}

Hydraulic efficiency of the gathering and transportation system reflects the process of «ageing» of field gas pipelines over time. The coefficient of hydraulic efficiency is generally considered a diagnostic feature, which is associated with the technical condition of the line gas pipe. Based on the value of the hydraulic efficiency coefficient at a certain point in time, a decision is taken on further operation of the gas transport facility or its transfer to service for carrying out restoration measures [1]. So, the reliability of the value of the hydraulic efficiency coefficient determines the strategy of further operation of the gas gathering, treatment and transportation system. The low numerical value of the hydraulic efficiency coefficient will lead to the operation of the field gas pipeline with fuel gas overconsumption or excessive system pressure losses.
The gas production system of Ukraine is a complex and knowledge-intensive industrial system whose gas pipelines have connecting pipes, connected to the main gas pipelines and underground storage facilities. The specificity of the system makes it possible to work in a single technological regime and to provide a high level of reliability and maneuverability in the processes of targeted gas production and supply, as well as gas supply in extreme situations.

At present, a considerable number of gas fields in Ukraine are in the final stage of operation. Gradual reduction of the formation pressure leads to a decrease in the average pressure in the gas production, gathering, treatment and transportation system (well - flowline - CGTP - field gas pipeline system - BCS - main gas pipeline). Accordingly, in order to achieve the required level of hydrocarbon production and extension of the field operation period, a coordinated 
functioning of each element of this system is necessary, and therefore pressure loss minimization in the gas gathering and transportation system is one of the urgent tasks.

\section{Literature review and problem statement}

The gas pipeline efficiency is mainly determined by the gas cleaning and dehumidification efficiency at complex gas treatment plants and headworks. The operating experience of gas pipelines suggests that non-compliant gas containing condensate, moisture, mechanical impurities, salts, resins for some reason enters field gas pipelines during the field development. In most cases, the liquid phase content in the gas flow is negligible [2]. Nevertheless, it substantially affects the pipeline friction and capacity. This is due to the fact that during the two-phase flow, redistribution of mixture phases takes place in the «shaped» pipeline, which leads to liquid accumulation in certain gas pipeline sections. Liquid, as a denser mixture component, is accumulated in the upstream pipeline sections and is practically absent in the downstream sections. This means that mixture density in the upstream gas pipeline sections is much higher than in the downstream ones.

The discrepancy of mixture density in the downstream and upstream gas pipeline sections is the root cause of additional friction. The value of friction essentially depends on the pipeline route profile and duration of operation on non-compliant gas and practically does not depend on the liquid content in the gas flow (condensation factor). The condensation factor affects only the growth rate of the gas pipeline friction during the initial operation period until all upstream pipeline sections are filled with liquid. At the same time, the pressure difference will reach the maximum value and the subsequent flow of liquid into the gas pipeline will not lead to higher friction losses [3, 4]. In the literature, data on the results of calculating the volume of deposits were practically not found, except [5], where the attempt to compare the effectiveness of methods is based on the similarity of the results obtained among themselves, but not with the actual data on the volume of pollutant removal from the field gas pipeline.

The attempt of researchers to compare calculation data using the above methods [6] shows that the values between them can differ 1.5-3 times. Due to the lack of perfect data on the actual pollution volume during the gas pipeline section pigging, it is impossible to determine the most accurate method.

The analysis of scientific-technical and patent information has shown that enough attention is paid to the problem of hydrate formation control in gas pipelines [7-11]. All patented methods for hydrate formation control are based on the principle of the gas flow rate, pressure and temperature measurement, density determination and selection of an equilibrium hydrate formation curve on their basis. According to the obtained values of pressure and temperature in the gas pipeline, on the basis of the hydrate formation curve, the start of hydrate formation is determined.

Other researchers [12,13], when analyzing the gas pipeline operation modes, obtain the hydraulic efficiency coefficient, the comparison of which with the permissible value allows judging the gas pipeline pollution.

The disadvantage of the first methods is the measurement complexity and isolation from the practice of gas pipeline operation. The second method does not regulate the permissible value of the hydraulic efficiency coefficient and also does not determine the pollution volume, since the operation modes of different gas pipelines cannot be characterized by one specific value of the coefficient. It is very important to know possible hydrate formation places for timely prevention. In order to correctly determine hydrate formation places, it is necessary to know the composition, density, pressure and temperature changes and gas humidity. Knowing the humidity and the composition of the gas supplied to gas pipelines, as well as the dependence of these parameters on pressure and temperature, it is possible to determine the place and the accumulation rate of the liquid phase in the gas pipeline, as well as the start time of hydrate formation. If the dew point is above the equilibrium hydrate formation curve, hydrates are formed at the intersection of the temperature curve in the gas pipeline with the equilibrium hydrate formation temperature curve. If the dew point lies below the equilibrium curve, but above the temperature curve minimum in the gas pipeline, hydrates are formed at the dew point.

The efficiency of the systems of gas gathering and transportation from the Company fields depends on the hydraulic condition of the aggregate sections of the line gas pipe (field, interfield, etc.). Therefore, periodic monitoring of the hydraulic condition is necessary in order to assess the actual hydraulic characteristics (determination of pressure differences, actual coefficients of friction of the section and hydraulic efficiency, estimated pollution volume).

As of the $80-90$-ies of the last century, much attention has been paid to the study of the two-phase flow. Models of gas and liquid flow in pipes and new methods for determining the liquid amount in the gas pipeline and methods of liquid removal have been developed, liquid removal devices have been upgraded. These include the method of creating the pulsed mode of the working gas flow (the so-called «Method of high-speed gas flow») [15]. Outside Ukraine, considerable attention is paid to pigging of gas pipelines by the method of passing the pigging devices of various designs. Methods of pigging of flowlines and gas pipelines with gel pistons [17] and surfactants [16], as well as methods of refined calculations of the hydraulic condition of gas condensate gas pipelines $[18,19]$ have been developed. In addition, gas cleaning in fields is significantly improved due to the creation of up-to-date separation equipment. As for Ukraine, today the only normative document regulating the hydraulic calculation procedure is VSN 51.1-85 [20], the provisions of which and developments of UkrNDIGas specialists are the basis of the software-calculation complex «Control of breakaway liquid release from gas pipelines». This complex consists of three interconnected programs: hydraulic efficiency, pollution volume and hydrate formation, on the basis of which the calculations were made, presented in [21]. All hydraulic calculations of gas pipelines are executed in accordance with the requirements $[14,20]$.

In view of this, it is promising to solve the problem of analyzing the operation modes of the gas gathering and transportation system, identifying the problem sections in terms of hydraulic efficiency degradation, and justifying the feasibility of gas pipeline pigging measures.

When solving the problem of gas pipeline pigging, it is necessary to find out the causes and quantity of liquid entry. This will allow monitoring any changes during operation and making decisions on the time of pigging. It should also be noted that the pollution volume in gas pipelines, calculated theoretically, differs from that determined experimentally. Therefore, the problem should be studied in detail. 
Besides, attention should be paid to differences in the approach to pigging of field pipelines, since, in accordance with the requirements of regulatory documents, a decision on pigging of this type of pipelines is made solely on the basis of an internal pipe inspection [22], which in fact cannot be carried out in Ukrainian specific conditions, covered in detail in [23]. Nevertheless, it should be noted that the multiphase medi$\mathrm{um}$, which is considered rather immobile during operation of mature fields or constantly changes the form when localized in the lowered places under the changing thermobaric operation mode will be formed in pipelines in any conditions [24]. On the other hand, the problem of the behavior of multiphase media under the changing thermobaric operation mode of pipelines is mainly covered for oil pipelines and runs of oil gathering mains, taking into account the possibility of formation of paraffin deposits [25] and resins [26, 27].

The processes of liquid accumulation in gas gathering systems are more specific, since such pollutants are more mobile than in oil pipelines at the initial stage of development, when gas condensate is the main pollutant, and more stable to localization at the final stage of field development, when formed exclusively from water fractions only with condensate traces. In any case, both Ukrainian and foreign experts suggest carrying out a comprehensive examination of pipeline sections where liquid accumulation is possible [28].

In the absence of clear normative guidance to such diagnostics, the analysis of hydraulic efficiency should be considered a fairly simple and cost-effective method, despite its significant error and high frequency.

\section{The aim and objectives of the study}

The aim of the study is to develop measures to improve the efficiency of the gas transportation system on the basis of determining the influence of liquid location in the gas pipeline on the hydraulic condition of the pipeline.

To achieve this aim, the following objectives were set:

- to conduct an analysis of the hydraulic condition of the major gas gathering main of the gas gathering system from the CGTP of the Shebelinske GCF;

- to investigate the locations and causes of the most probable pollution;

- to develop measures for liquid removal from the gas pipeline.

Implementation of measures for liquid removal from the gas pipeline, which involves liquid drainage from the gas gathering main by installing a looping and using a specialized liquid removing device, allows carrying out drainage without stopping the gas pipeline operation.

\section{Materials and methods of the study}

The object of the study was the gas gathering and transportation system of the Ukrgasvydobuvannya PJSC (Company) (Kyiv, Ukraine), which includes 9272 kilometers of field pipelines (interfield gas pipelines, flowlines, connecting gas pipelines) and is the leading gas producing enterprise in Ukraine. Justification of expediency of considering such an object may be the fact that an increase in the hydraulic efficiency coefficient of the field gas pipeline system of the Ukrgasvydobuvannya PJSC by only $1 \%$ can lead, under steady conditions, to an increase in the annual gas production volume by more than 152 million cubic meters. Special attention should also be paid to the time trend of the hydraulic efficiency coefficient. A sharp drop in its numerical value indicates a change in the technical condition of the line gas pipe, the cause of which should be urgently established by the additional use of special diagnostic methods in order to prevent emergency situations. In the sphere of operation of the field gas pipeline system, it is important to be confident in the reliability of determining the hydraulic efficiency coefficient as a diagnostic feature. That is why it is worth to note the important role of the condition of gas treatment equipment (separation equipment, gas treatment units, gas dehydration units and other equipment) in the value of the hydraulic efficiency coefficient.

Investigation of the hydraulic condition of gas pipeline sections of the Company is carried out in accordance with the internal normative documents [14]. Pressure measurements on block valve stations and connecting pipes and inspection of devices are provided once a month. Determination of the hydraulic efficiency of the gas pipeline and places of liquid accumulation and crystalline hydrate formation - as needed. Determination of the possibility of passing pigging devices is carried out before the scheduled passing of pigging devices based on the results of determining the hydraulic efficiency.

As a result of the breakaway liquid release from the gas pipeline, the formation of hydraulic and hydrate blocks may lead to an emergency situation, which will result in the termination of gas supply to consumers. In order to prevent emergency failures of equipment, the analysis of the hydraulic condition of potentially hazardous areas is most effective in the following periods of year:

- during preparation for the winter period of operation of the gas pipeline of the gas producing enterprise, in connection with the increased gas supply to the adjacent consumers;

- in the winter-spring period of operation, as the most favorable for liquid condensation from the gas flow during its transportation;

- during any change in the gas pipeline operation mode caused by the connection of new fields, changes in operational pressure, redistribution of gas flows in the gas pipeline system, emergency failures of equipment in fields, etc.

The distribution of the Company's gas pipelines by diameter is as follows: $\varnothing 89 \mathrm{~mm}-58 \%, \varnothing 89-114 \mathrm{~mm}-4 \%$, $\varnothing 159-273 \mathrm{~mm}-34 \%, \varnothing 273-1,000 \mathrm{~mm}-4 \%$. The age of the gas gathering, treatment and transportation system of the Company of more than 40 years $-34 \%, 20$ years $-26 \%$, 10 years $-20 \%$, up to 10 years $-20 \%$.

The gas producing enterprise Ukrgasvydobuvannya PJSC includes three GPD: Shebelinkagasvydobuvannya, Poltavagasvydobuvannya and Lvivgasvydobuvannya, which carry out the main functions of production, treatment and transportation of gas to the points of transmission to the main gas pipelines. The total fund of the Ukrgasvydobuvannya PJSC is more than 2,700 wells, 140 fields, 39 booster compressor stations are operated, gas treatment is carried out on 184 complex gas treatment plants.

The Shebelinkagasvydobuvannya gas production department has five oil, gas and condensate production shops (OGCPS): Shebelinskyi OGCPS, Efremivskyi OGCPS, Severodonetska Operations Service (OS) of Shebelinskyi OGCPS, Pereshchepynska OS of Yuliivskyi OGCPS, Yuliivska OS of Yuliivskyi OGCPS. Gas production, gathering and treatment are carried out on the above-mentioned OGCPS with the subsequent transfer to the main gas pipelines. The length of field gas pipelines in the gas produc- 
tion department is about $3,570 \mathrm{~km}$. The volume of the gas produced by this gas production department is 8.5 billion cubic meters a year, accounting for $55 \%$ of the Company's total production.

In view of the fact that the Shebelinske GCF is the most powerful field of the Shebelinkagasvydobuvannya GPD, since its production volumes form the main gas flows in the Kharkiv industrial region, gas gathering is performed precisely from the wells of this field on 24 CGTP. After preliminary treatment, gas is supplied by the system of ring gathering mains of the Shebelinske GCF (Shebelinskyi gas gathering main) to two central gas gathering stations: Chervonodonetska BCS and Shebelinka-1 CBCS. After gas treatment and compression on the Chervonodonetska $\mathrm{BCS}$ and the Shebelinka-1 CBCS, the gas is distributed to the MGP system as follows:

- gas is supplied to SHDKRI MGP after compression on 2 stages of the Chervonodonetska BCS;

- the gas of adsorber recovery of the Chervonodonetska BCS is supplied to the SHDK MGP on the section from the valve $21 \mathrm{~B}$, on the outlet header;

- the gas needed to cover consumer needs is supplied from the Shebelinka-1 CBCS and Chervonodonetska BCS to the Shebelinka - Kharkiv MGP;

- gas from the Shebelinka-1 CBCS, which was unsold in the summer period in the Shebelinka-Kharkiv MGP and gas from the CGTP of the Bezpalivske GCF is supplied to the SRO MGP.

In 2017, the authors conducted a study of the hydraulic condition of sections of the DN 700 major gas gathering main of the Shebelinske GCF. The studies were carried out by measuring the pressure at the control points of the major gas gathering main on the following sections:

1 - «valve 20a - CGTP-9 $(L=0.3 \mathrm{~km}) »$;

$1^{\prime}$ - «Looping» valve $20 \mathrm{a}$ - valve 8 (32)» (commissioned as of 01.08.2017)»;

2 - «CGTP-9 - valve $35(L=0.2 \mathrm{~km}) »$;

3 - «valve 35 - valve $32($ CGTP-10) $(L=2.1 \mathrm{~km}) »$;

$3^{\prime}$ - «valve 32 - valve $9(\mathrm{CGTP}-11)(L=1.36 \mathrm{~km}) »$;

4 - «valve 9 - valve $54(L=2.14 \mathrm{~km}) »$;

5 - «valve 54 - valve 99 (Chervonodonetska BCS junction point) $(L=1.0 \mathrm{~km}) \gg$;

6 - «valve 99 - drip outlet of the 1st stage of the Chervonodonetska BCS $(L=0.3 \mathrm{~km}) »$;

7 - «drip outlet of the 1 st stage of the Chervonodonetska BCS - horizontal adsorption unit outlet of the Chervonodonetska BCS».

Particularly noteworthy is the situation that arose in February 2017, when the gas production department experts recorded a significant increase in the liquid flow from the Shebelinske GCF gas gathering main to the Chervonodonetska BCS inlet. This situation has led to complications in the operation of compressor units. Therefore, according to the relevant order, experts of the gas production department took a sample of the liquid that came from the major gas gathering main to the separation equipment of the Chervonodonetska BCS for analysis to determine the chemical composition and origin.

The result of the analysis of the liquid phase revealed that samples of acid water with a significant concentration of organic acids, pitting chloride ions and iron ions, which indicates corrosion activity, were given for the studies. After the analysis of the sediment, it was determined that it contains the same ions as in water. This may indicate that the sediment is formed of water. In this case, the amount of calcium, magnesium, sulfate, bicarbonate and iron ions in the sediment increased (Table 1).

The presence of iron ions is due to corrosion processes. In particular, the presence of $\mathrm{Fe}^{3+}$ ions in the sediment is caused by the oxidation of $\mathrm{Fe}^{2+}$ ions. An increase in the concentration of calcium, magnesium, bicarbonate and sulfate ions is due to the lower water solubility of calcium and magnesium sulfates and bicarbonates, compared to the solubility of calcium and magnesium chlorides.

Table 1

Composition and properties of water and sediment samples

\begin{tabular}{|c|c|c|}
\hline \multirow{2}{*}{ Indicator } & \multicolumn{2}{|c|}{ Value } \\
\hline & Water, $\mathrm{mg} / \mathrm{l} / \%^{(1)}$ & Sediment, \% wt. \\
\hline Mineralization & $84554.3^{(2)}$ & - \\
\hline Water solubility at $20^{\circ} \mathrm{C}$ & & 90 \\
\hline $\mathrm{PH}$ & $5.6^{(3)}$ & - \\
\hline Density & $1.055^{(4)}$ & - \\
\hline \multicolumn{3}{|l|}{ Concentration of: } \\
\hline - mechanical impurities & $0.41^{(5)}$ & - \\
\hline$-\mathrm{Fe}^{2+}$ iron ions & $139.6 / 0,17$ & 0 \\
\hline$-\mathrm{Fe}^{3+}$ ions & 0 & 25.0 \\
\hline$-\mathrm{Cl}^{-}$chloride ions & $43970.4 / 52$ & 42.0 \\
\hline$-\mathrm{Ca}^{2+}$ calcium ions & $5611.2 / 6,6$ & 30 \\
\hline$-\mathrm{Mg}^{2+}$ magnesium ions & $3040.0 / 3,6$ & 15 \\
\hline$-\mathrm{HCO}_{3}{ }^{-}$bicarbonate ions & $183 / 0.21$ & 12 \\
\hline $\begin{array}{l}- \text { amount of } \mathrm{Na}^{+}+\mathrm{K}^{+} \text {sodi- } \\
\text { um and potassium ions }\end{array}$ & $31570.0 / 37.3$ & 30 \\
\hline$-\mathrm{SO}_{4}^{2-}$ sulfate ions & $30 / 0.04$ & 27 \\
\hline $\begin{array}{l}\text { - volatile organic acids (as } \\
\text { acetic acid) }\end{array}$ & $182.4^{(2)}$ & - \\
\hline
\end{tabular}

Notes: (1) The denominator shows the share from water mineralization. (2) $\mathrm{mg} / \mathrm{m}^{3}$. (3) Without dimension. (4) $\mathrm{g} / \mathrm{cm}^{3}$. (5) $w \mathrm{t} . \%$

The corrosion activity of water and deposition of salts from water can be one of the causes of the complicated operation of pipelines, CGTP, BCS and other process equipment. A special danger arises when a part of the liquid condensed in the pipeline covers the layer of solid deposits and causes corrosion damage to the gas pipeline wall [29]. Under conditions of low turbulence of the gas flow, solid deposits can be accumulated at the bottom of the horizontal or slightly inclined line of the gas pipeline.

\section{Results of the analysis of the hydraulic condition of the major gas gathering main of the system of gas gathering from the CGTP of the Shebelinske GCF}

The results of the measurements of the key parameters of sections of the DN 700 major gas gathering main of the Shebelinske GCF are given in Table 2. Table 3 shows the results of the assessment of the hydraulic condition of the studied sections. The comparative analysis and assessment of the dynamics of the hydraulic condition parameters of sections of the major gas gathering main are given in Table 4. The table shows the key indicators according to the results of studies conducted in the period of 2016-2017. 
Table 2

Results of measurement of operating parameters of the DN 700 major gas gathering main of the Shebelinske GCF (gas supply to the Chervonodonetska BCS) as of 02.03.2017

\begin{tabular}{|c|c|c|c|c|}
\hline Gas pipeline section & Initial pressure, $P_{\text {in }}$, atm & Final pressure, $P_{\text {fin }}$, atm & Average gas temperature, $T,{ }^{\circ} \mathrm{C}$ & Section capacity, $Q, \mathrm{mln} \mathrm{m}^{3} /$ day \\
\hline 1 & 6.645 & 6.584 & 2.02 & 0.617 \\
\hline 2 & 6.584 & 6.442 & 1.81 & 0.783 \\
\hline 3 & 6.442 & 6.28 & 1.56 & 1.834 \\
\hline $3 \nsubseteq$ & 6.28 & 6.143 & 1.32 & 3.458 \\
\hline 4 & 6.143 & 5.73 & 1.04 & 3.587 \\
\hline 5 & 5.789 & 5.48 & 0.82 & 4.329 \\
\hline 6 & 5.48 & 5.344 & 0.51 & 4.329 \\
\hline 7 & 5.344 & 5.078 & 0.5 & 4.329 \\
\hline
\end{tabular}

Table 3

Results of the assessment of the hydraulic condition of the DN 700 major gathering main of the Shebelinske GCF according to research results of 02.03.2017

\begin{tabular}{|c|c|c|c|c|c|c|c|}
\hline $\begin{array}{l}\text { Gas } \\
\text { pipeline } \\
\text { section }\end{array}$ & $\begin{array}{l}\text { Pres- } \\
\text { sure } \\
\text { loss, atm }\end{array}$ & $\begin{array}{l}\text { Excess } \\
\text { loss, } \\
\text { atm }\end{array}$ & $\begin{array}{l}\text { Gas } \\
\text { velocity, } \\
\mathrm{m} / \mathrm{s}\end{array}$ & $\begin{array}{l}\text { Hydraulic } \\
\text { efficiency } \\
\text { coefficient \% }\end{array}$ & $\begin{array}{l}\text { Estimated } \\
\text { pollution } \\
\text { volume, } \mathrm{m}^{3}\end{array}$ & $\begin{array}{l}\text { Critical. } \\
\text { pollution } \\
\text { volume, } \mathrm{m}^{3}\end{array}$ & Conclusion on the operation mode \\
\hline 1 & 0.07 & 0.07 & 2.67 & 13.89 & 7.758 & 7.17 & $\begin{array}{l}\text { Gas pipeline section is polluted, } 7.758 \mathrm{~m}^{3} \text { are accumula- } \\
\text { ted, gas velocity promotes liquid sedimentation during gas } \\
\text { transportation, excess pressure loss }-0.07 \text { atm, probabi- } \\
\text { lity of breakaway liquid release to the next section }\end{array}$ \\
\hline 2 & 0.14 & 0.14 & 3.44 & 10.23 & 8.1 & 6.69 & $\begin{array}{l}\text { Gas pipeline is polluted, } 8.1 \mathrm{~m}^{3} \text { are accumulated, gas ve- } \\
\text { locity promotes liquid sedimentation during gas trans- } \\
\text { portation, excess pressure loss }-0.14 \text { atm, probability of } \\
\text { breakaway liquid release to the next section }\end{array}$ \\
\hline 3 & 0.16 & 0.08 & 8.32 & 73.38 & 7.7 & 19.04 & $\begin{array}{l}\text { Gas pipeline section has accumulated } 7.7 \mathrm{~m}^{3} \text {, gas velo- } \\
\text { city promotes liquid sedimentation, excess pressure loss - } \\
0.08 \mathrm{~atm}\end{array}$ \\
\hline 3 & 0.14 & 0.03 & 16.06 & 89.09 & 2.08 & 6.09 & $\begin{array}{l}\text { Gas pipeline section has accumulated } 2.08 \mathrm{~m}^{3} \text {, gas velocity } \\
\text { promotes liquid removal, excess pressure loss - } 0.03 \mathrm{~atm}\end{array}$ \\
\hline 4 & 0.41 & 0.05 & 17.39 & 93.54 & 0 & 0 & Gas pipeline section is clean \\
\hline 5 & 0.31 & 0.05 & 22.09 & 90.91 & 1.265 & 2.7 & $\begin{array}{l}\text { Gas pipeline section has accumulated } 1.265 \mathrm{~m}^{3} \text {, gas veloci- } \\
\text { ty promotes liquid removal, excess pressure loss }-0.05 \mathrm{~atm}\end{array}$ \\
\hline 6 & 0.14 & 0.06 & 23.0 & - & - & - & $\begin{array}{l}\text { Gas velocity promotes liquid removal, pressure loss is due } \\
\text { to local frictions in separation equipment }\end{array}$ \\
\hline 7 & 0.266 & - & - & - & - & - & $\begin{array}{l}\text { Pressure loss is due to local frictions in separation equip- } \\
\text { ment }\end{array}$ \\
\hline
\end{tabular}

Table 4

Comparative table of the results of the assessment of the hydraulic condition of sections of the DN 700 major gathering main of the Shebelinske GCF conducted from November 28 to December 2, 2016 and February 03, 2017

\begin{tabular}{|c|c|c|c|c|c|c|c|c|c|c|}
\hline \multirow{2}{*}{$\begin{array}{c}\text { Gas } \\
\text { pipeline } \\
\text { section }\end{array}$} & \multicolumn{5}{|c|}{ Study on $28.11 .2016-02.12 .2016$} & \multicolumn{5}{|c|}{ Study on 03.02 .2017} \\
\hline & $P_{a v}$, atm & $\begin{array}{c}Q, \\
\mathrm{mln} \mathrm{m}^{3} / \text { day }\end{array}$ & $\Delta P$, atm & $\begin{array}{c}\text { Pollution } \\
\text { volume, } \mathrm{m}^{3}\end{array}$ & $\begin{array}{l}\text { Hydraulic effi- } \\
\text { ciency, E, \% }\end{array}$ & $P_{a v}$, atm & $\begin{array}{c}Q, \\
\mathrm{mln} \mathrm{m}^{3} / \text { day }\end{array}$ & $\Delta P$, atm & $\begin{array}{c}\text { Pollution } \\
\text { volume, } \mathrm{m}^{3}\end{array}$ & $\begin{array}{l}\text { Hydraulic effi- } \\
\text { ciency, } E, \%\end{array}$ \\
\hline 1 & 6.58 & 0.5618 & 0.02 & 6.84 & 28.34 & 6.62 & 0.617 & 0.07 & 7.758 & 13.89 \\
\hline 2 & 6.565 & 0.7346 & 0.01 & 5.79 & 36.16 & 6.51 & 0.783 & 0.14 & 8.1 & 10.23 \\
\hline 3 & 6.53 & 2.2636 & 0.07 & 0.00 & 100.0 & 6.36 & 1.834 & 0.16 & 7.7 & 73.38 \\
\hline 4 & 6.231 & 3.6817 & 0.26 & 2.69 & 91.99 & 5.94 & 3.587 & 0.41 & 0 & 93.54 \\
\hline 5 & 6.03 & 4.4419 & 0.14 & 0 & 98.99 & 5.64 & 4.329 & 0.31 & 1.265 & 90.91 \\
\hline 6 & 5.9 & 4.4419 & 0.12 & - & 86.34 & 5.41 & 4.329 & 0.14 & 1.345 & 75.56 \\
\hline 7 & & No me & asurement & s were made & & 5.21 & 4.329 & 0.266 & - & - \\
\hline
\end{tabular}




\section{Results of the research of the most probable pollution locations}

To track possible liquid locations, Fig. 1 shows the profile plan of the route of the system of gas gathering from the Shebelinske GCF (Shebelinskyi gas gathering main).

Table 5 shows the list of problem sections of gas pipelines of the gathering and transportation system of gas from the fields of Shebelinkagasvydobuvannya GPD with excessive pressure loss due to pollution accumulation.

Table 6 shows the results of studies of the hydraulic condition of the major gas gathering main in the spring-summer and autumn-winter operation periods of 2017. This table is presented for the comparative analysis and assessment of changes in the basic parameters of hydraulic characteristics of sections of the studied gas pipelines (pressure difference on the section, hydraulic efficiency coefficient, estimated pollution volume).

From January to February 2017, at the Chervonodonetska BCS inlet of the Shebelinske GCF, there were large volumes of flow of liquid from the gas gathering main (about $152 \mathrm{~m}^{3}$ a day) saturated with hematite, clay residues and other mechanical mixtures. The liquid was not caught in full on the separation equipment of the CGTP, dust collectors and expansion chamber of the compressor shop of the ChBCS. The flow of the liquid phase into the inlet of the ChBCS compressor units has led to failure of valves, pistons, and sealing glands. The situation had a negative effect on the stable operation of the Chervonodonetska BCS compressor shop and led to losses of gas production from the Shebelinske GCF [30].

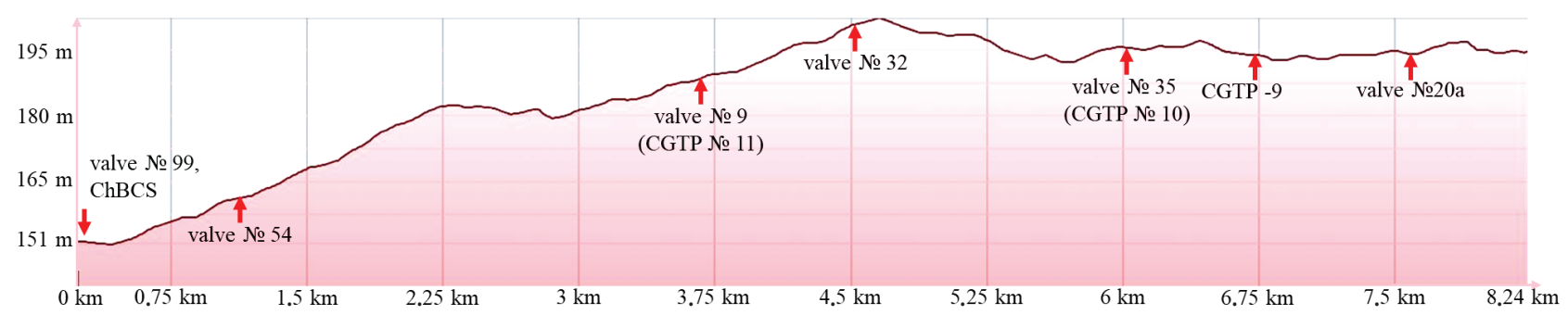

Fig. 1. Profile plan of the route of the DN 700 major gas gathering main «valve 99 - valve 20a» (gas supply to the Chervonodonetska BCS)

Table 5

List of problem sections of gas pipelines, according to the results of the hydraulic condition studies during the autumn-winter operation period of 2017

\begin{tabular}{|c|c|c|c|c|}
\hline Section & $\begin{array}{l}\text { Pressure loss, } \\
\text { (total/excess), atm }\end{array}$ & $\begin{array}{l}\text { Hydraulic efficien- } \\
\text { cy coefficient, \% }\end{array}$ & $\begin{array}{l}\text { Estimated pollution } \\
\text { volume, } \mathrm{m}^{3}\end{array}$ & $\begin{array}{l}\begin{array}{l}\text { Recommendations on hydraulic condition } \\
\text { improvement }\end{array} \\
\end{array}$ \\
\hline \multicolumn{5}{|c|}{$\begin{array}{l}\text { Gas pipeline sections of the system of gas gathering and transportation from the CGTP } \\
\text { of the Shebelinske GCF to the Chervonodonetska BCS }\end{array}$} \\
\hline $\begin{array}{l}\text { CGTP 20a- } \\
\text { CGTP-9 pipeline }\end{array}$ & $0.07 / 0.07$ & 13.89 & 7.758 & $\begin{array}{l}\text { Requires constant hydraulic condition mo- } \\
\text { nitoring }\end{array}$ \\
\hline CGTP-9 - valve 35 & $0.7 / 0.7$ & 7.77 & 8.63 & $\begin{array}{l}\text { Requires constant hydraulic condition mo- } \\
\text { nitoring }\end{array}$ \\
\hline $\begin{array}{l}\text { Looping «valve } 20 \mathrm{a}- \\
\text { valve } 8 »\end{array}$ & $0.3 / 0.3$ & 12.72 & 36.5 & $\begin{array}{l}\text { Requires constant hydraulic condition mo- } \\
\text { nitoring. Consider tapping for mobile drai- } \\
\text { nage devices }\end{array}$ \\
\hline
\end{tabular}

Table 6

Comparative table of the results of the assessment of the hydraulic condition of sections of the system of gas gathering from the CGTP of the Shebelinske GCF conducted in the spring-summer and autumn-winter periods of 2017

\begin{tabular}{|c|c|c|c|c|c|c|c|c|c|c|}
\hline \multicolumn{11}{|c|}{ DN 700 major gas gathering main, supply to the ChBCS } \\
\hline \multirow[b]{2}{*}{$\begin{array}{l}\text { Gas } \\
\text { pipeline } \\
\text { section }\end{array}$} & \multicolumn{5}{|c|}{ Spring-summer period 2017} & \multicolumn{5}{|c|}{ Autumn-winter period 2017} \\
\hline & $\begin{array}{c}\text { Average } \\
\text { pressure } P_{a v}, \\
\text { atm }\end{array}$ & $\begin{array}{l}\text { Capacity } Q \\
\mathrm{mln}^{3} / \text { day }\end{array}$ & $\begin{array}{c}\text { Pressure } \\
\text { difference } \Delta P \text {, } \\
\text { atm }\end{array}$ & $\begin{array}{c}\text { Hydraulic } \\
\text { efficiency, } \\
E, \%\end{array}$ & $\begin{array}{c}\text { Pollution } \\
\text { volume, } \\
\mathrm{m}^{3}\end{array}$ & $\begin{array}{l}\text { Average } \\
\text { pressure } \\
P_{a v}, \text { atm }\end{array}$ & $\begin{array}{l}\text { Capacity } Q, \\
\mathrm{mln}^{3} / \text { day }\end{array}$ & $\begin{array}{c}\text { Pressure } \\
\text { difference } \\
\Delta P, \text { atm }\end{array}$ & $\begin{array}{c}\text { Hydraulic } \\
\text { efficiency, } \\
\qquad E \%\end{array}$ & $\begin{array}{c}\text { Pollution } \\
\text { volume, } \\
\mathrm{m}^{3}\end{array}$ \\
\hline 1 & 6.98 & 0.8771 & 0.01 & - & - & 6.51 & 0.2382 & 0.01 & - & - \\
\hline $1^{\prime}$ & - & - & - & - & - & 6.36 & 0.6021 & 0.3 & 12.72 & 36.5 \\
\hline 2 & 6.89 & 1.0429 & 0.163 & 12.32 & 6.19 & 6.47 & 0.3462 & 0.07 & 7.77 & 8.63 \\
\hline 3 & 6.65 & 2.2199 & 0.328 & 61.83 & 10.54 & 6.32 & 1.5845 & 0.22 & 50.49 & 12.73 \\
\hline 3 & 6.41 & 3.7303 & 0.143 & 92.78 & 0 & 6.14 & 3.6767 & 0.14 & 95.74 & 0 \\
\hline 4 & 6.09 & 3.8375 & 0.509 & 90.75 & 2.79 & 5.91 & 3.8241 & 0.32 & 84.7 & 4.67 \\
\hline 5 & 5.66 & 4.4564 & 0.351 & 90.09 & 1.5 & 5.58 & 4.5559 & 0.35 & 83.89 & 1.74 \\
\hline 6 & 5.42 & 4.4564 & 0.68 & - & - & 5.3 & 4.5559 & 0.21 & - & - \\
\hline
\end{tabular}




\section{Development of measures for liquid removal from gas pipelines}

In order to prevent the failure of the compressor equipment on the Chervonodonetska BCS and to increase the efficiency of the Shebelinske GCF gas gathering system, measures were developed to increase the efficiency of the system of gas gathering from the CGTP of the Shebelinske GCF. Among the planned measures, the following works were provided:

- liquid drainage from the DN 700 gas gathering main at the valve 8 under pressure without stopping the gas pipeline operation;

- connection of an additional gas pipeline between the valves 20a and 8 under pressure without stopping the gas pipeline operation.

The works on liquid removal were carried out in JuneJuly 2017 under pressure, without the gas production stopping and gas release into the atmosphere. In the process of works, the device for liquid removal from the pipeline was used (Fig. 2) [30].

The main objective of this work was to remove liquid from the DN 700 gathering main on the section between the CGTP-5 and the valve 8 . The use of the hot tapping technology allows eliminating gas losses during the drainage tapping in comparison with the traditional method with stopping the gas pipeline operation and gas release in the atmosphere. It also excludes the stopping of gas production from CGTP-2 and CGTP-5 of the Shebelinske GCF.

The works on the liquid phase removal include the developed technological complex for liquid drainage from the field gas pipeline. This complex includes preparatory works, installation of the «Device for liquid removal from the pipeline» (Fig. 2, $a$ ), liquid drainage into a tank truck (Fig. 2, $b$ ) and finishing works.

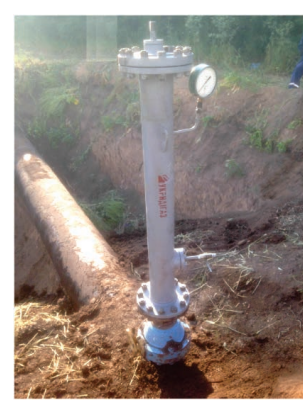

a

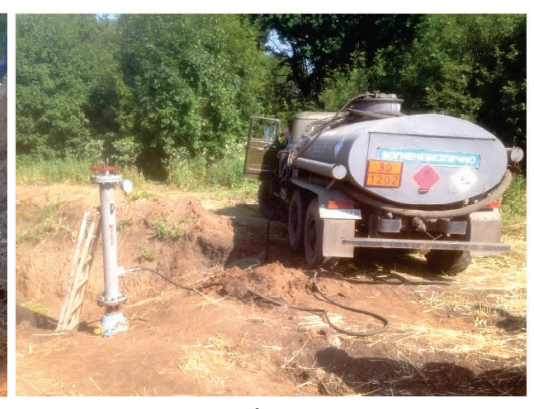

$b$
Fig. 2. Device for liquid removal from the pipeline $(a)$ and the process of liquid drainage into a tank truck $(b)$

The next stage of the planned measures was the connection of 2 branches of DN 700 to the gas gathering main in the area between the valves $20 \mathrm{a}$ and 8 . The works were also carried out under pressure, without the gas production stopping and gas release into the atmosphere. In the course of the works, modern equipment of the TD Williamson company (hydraulically-operated tapping machine TM-1200N) was used (Fig. 3) [30].

The aim of this work was to increase the efficiency of the system of gas gathering from the CGTP of the Shebelinske GCF by connecting the DN 1000 looping between the valve $20 \mathrm{a}$ and the valve 8 . This made it possible to reduce pressure differences in the DN 700 major gas gathering main and to lower the working pressure at the wellhead. For this, the new «Additional first compression stage gas pipeline of the Chervonodonetska BCS» with the total length of $3.638 \mathrm{~km}$ and an equivalent diameter of $949 \mathrm{~mm}$ was used.

The works on the connection of 2 branches of DN 700 to the gas gathering main in the area of the valve 8 and the valve 20a included the developed complex of works. The complex included preparation, hot tapping, using modern equipment of the TD Williamson company (Fig. 3) and finishing works (Fig. 4) [30].

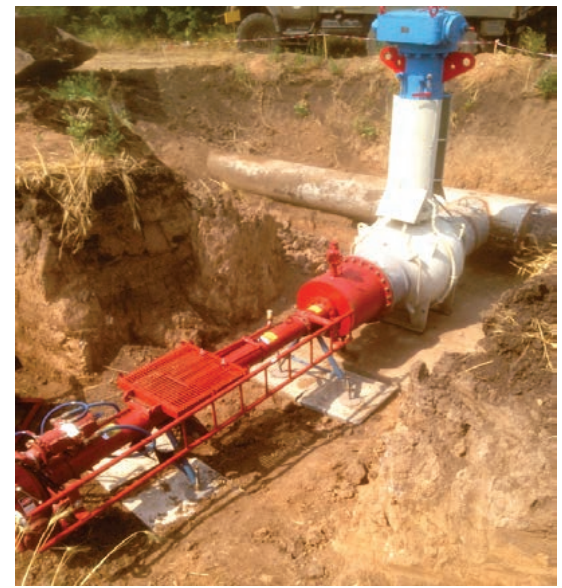

Fig. 3. TD Williamson hydraulically-operated tapping machine with the housing adapter mounted to the branch connection

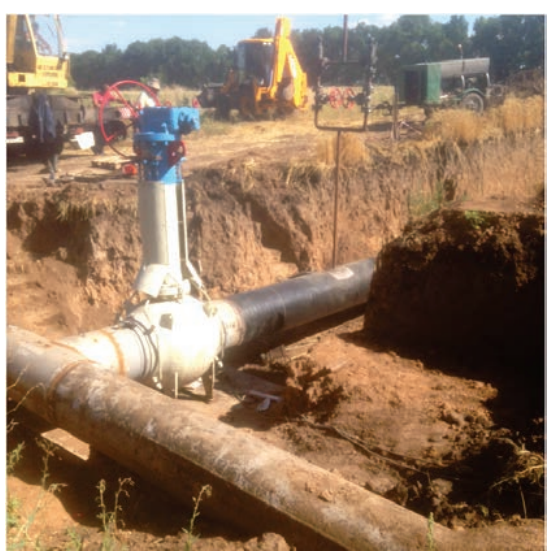

Fig. 4. DN 700 branch welded to the DN 1000 looping at the valve 8

\section{Discussion of the results of development} of technical solutions for the gas transportation system efficiency improvement

According to the results of the research of the hydraulic condition of sections of the DN 700 major gas gathering main of the Shebelinske GKR (as of February 3, 2017), we can note the following:

- on the initial sections of the gathering main «valve 20a - CGTP-9 pipeline» and «CGTP-9 pipeline - valve 35 (CGTP-10 pipeline)», there is a probability of breakaway liquid release to the following sections, since the pollution volume on the sections exceeds critical values; 
- on the section «valve 35 (CGTP-10 pipeline) - valve 32», gas velocity promotes liquid accumulation;

- on the following sections, starting from the valve 32 , gas velocity promotes movement of liquid masses along the gas pipeline, followed by the flow to the separation equipment of the Chervonodonetska BCS.

The comparative analysis of estimates of the hydraulic condition of the linear sections of the DN 700 major gas gathering main of the Shebelinske GCF according to the results of the research (November-December 2016 and February 2017) is given in Table 4 . The results are presented below (Table 7 ). The results show that on all sections there was a decrease in the hydraulic efficiency coefficient and an increase in the pollution volume, which indicates the flow of liquid to the gathering main.

To collect liquid from the DN 700 major gas gathering main, it is necessary to consider the possibility of installing the «expansion chamber» type condensate tank on the final section of the gas pipeline in a lowered position between the valve 54 and the valve 99 .

As a result of works on tapping and liquid drainage from the DN 700 gas gathering main of the Shebelinske GCF at the valve $8,27.635 \mathrm{~m}^{3}$ of liquid were removed.

On the basis of studies of the hydraulic condition of the gas gathering main, the places of most probable pollution accumulation were localized. As a result, the decision to perform works on liquid removal from this field gas pipeline at the valve 8 was made, and works on tapping and liquid drainage were carried out. The use of the hot tapping technology enabled the company to gain a positive economic effect (about 66.23 thousand US dollars, the calculation is given below) [30].

Calculation of the economic effect from the introduction of the technology of hot tapping and liquid drainage from the gas pipeline under pressure is carried out according to the following procedure.

$$
Q_{\text {releasevolume }}=\frac{2893.9}{T} \cdot V \cdot\left[\frac{P_{p}}{Z_{p}}-\frac{P_{k}}{Z_{k}}\right],
$$

where $T$ is the gas temperature on the disconnected section, $\mathrm{K} ; V$ is the geometric volume of the gas pipeline section, $\mathrm{m}^{3} ; P_{p}, P_{k}$ is the absolute average gas pressure on the gas pipeline section before and after emptying, $\mathrm{MPa} ; Z_{p}, Z_{k}$ are the corresponding coefficients of gas compressibility on the disconnected section.

By substituting the initial data, we obtain the volume of gas produced on the gas pipeline section:

$$
Q_{\text {releasezolume }}=\frac{2893.9}{284.5} \cdot 2206 \cdot\left[\frac{0.749}{0.98}-\frac{0.1}{1.0}\right]=14,906 \text { ths.m. }
$$

We will calculate gas losses from the termination of production from the CGTP-2, CGTP-5, working on this section during the gas pipeline stopping:

$$
Q_{\text {prod.term. }}=\left[Q_{C G T P-2}+Q_{C G T P-5}\right] \cdot \frac{\tau}{24},
$$

where $Q_{C G T P-2}, Q_{C G T P-5}$ is the daily gas production from the CGTP-2, CGTP-5, respectively, ths. $\mathrm{m}^{3} ; \tau$ is the duration of production termination during the works in the traditional way.
By substituting the data, we will get a reduction in gas production on the given CGTP, due to its termination during works with the gas pipeline stopping:

$$
Q_{\text {prod.term. }}=[196.0+254.0] \cdot \frac{27.84}{24}=522.0 \text { ths. m. }
$$

Let us determine the total gas losses during works with the gas pipeline stopping by the formula:

$$
Q_{\text {total }}=Q_{\text {prod.term. }}+Q_{\text {releasezolume }} .
$$

By substituting the estimated data, we will get the total volume of gas losses during works with the gas pipeline section stopping with gas release in the atmosphere and termination of gas production from the CGTP.

$$
Q_{\text {total }}=14.906+522.0=536.906 \text { ths. } \mathrm{m} \text {. }
$$

Let us calculate the economic effect according to the following formula:

$$
E=\left(P-C_{s v}\right) \cdot Q_{\text {total }}-B_{i},
$$

where $P$ is the gas sale price (without VAT), UAH/ths. $\mathrm{m}^{3}$; $C_{S v}$ is the semivariable cost of gas production by the Company, UAH/ths. $\mathrm{m}^{3}$; $Q_{\text {tot }}$ is the total pressure loss, ths. $\mathrm{m}^{3}$; $B_{i}$ is the cost of the measures, UAH:

$$
\begin{aligned}
& E=(4849.0-1525.98) \cdot 536.906-62564.98= \\
& =1721854.39 \mathrm{UAH}=66,23 \text { ths. USdol. }
\end{aligned}
$$

As a result of the works on connecting 2 branches of DN 700 to the gas gathering main DN 700 of the Shebelinske GKR between the valves $20 \mathrm{a}$ and 8 and the commissioning of the DN 1000 looping:

- pressure difference on the major gathering main on the section from the valve 20a to the valve 8 decreased by $0.201 \mathrm{~atm}$ (from $0.501 \mathrm{~atm}$ according to research data in May 2017 to $0.3 \mathrm{~atm}$ according to research data in November 2017);

- total pressure difference on the major gathering main on the section from the valve 20 a to the valve 99 decreased by $0.3941 \mathrm{~atm}$ (from $1.504 \mathrm{~atm}$ according to research data in May 2017 to $1.11 \mathrm{~atm}$ according to research data in November 2017);

- the works on the gas pipeline pigging promoted a decrease in the excess pressure difference and led to fuel cost reduction to $5 \%$;

- the use of the technology of connection of DN 700 branches under pressure allowed eliminating gas losses due to stopping the gas pipeline section, resulting in an economic effect for the Company amounted to 125 thousand US dollars [30]. Calculation of the economic effect for this gas pipeline section is made similarly with the formulas (1)-(4).

Comparison of the results of the assessment of the hydraulic condition of the major gas gathering main sections conducted in the spring-summer, autumn-winter periods and after the above-mentioned measures is presented in Table 7 .

To predict further changes in the hydraulic condition of the gas gathering and transportation system, the first stage of development of the online hydraulic efficiency monitoring system is proposed. For its implementation, the database of operational indicators is accumulated on the basis of the online monitoring system for wells. 
Table 7

Comparative table of the results of the assessment of the hydraulic condition of the major gas gathering main sections, conducted in the spring-summer, autumn-winter periods and after the above-mentioned measures

\begin{tabular}{|c|c|c|c|c|c|c|c|c|c|}
\hline \multirow{2}{*}{$\begin{array}{c}\text { Gas } \\
\text { pipeline } \\
\text { section }\end{array}$} & \multicolumn{2}{|c|}{ Spring-summer period 2017} & \multicolumn{2}{c|}{15.08 .2017 (after the measures) } & \multicolumn{3}{c|}{ Autumn-winter period 2017} \\
\cline { 2 - 11 } & $\begin{array}{c}\text { Pressure } \\
\text { difference }\end{array}$ & $\begin{array}{c}\text { Hydraulic } \\
\text { efficiency, } \\
E, \%\end{array}$ & $\begin{array}{c}\text { Pollution } \\
\text { volume, } \\
\mathrm{m}^{3}\end{array}$ & $\begin{array}{c}\text { Pressure } \\
\text { difference } \\
\Delta P, \text { atm }\end{array}$ & $\begin{array}{c}\text { Hydraulic } \\
\text { efficiency, } \\
E, \%\end{array}$ & $\begin{array}{c}\text { Pollution } \\
\text { volume, } \\
\mathrm{m}^{3}\end{array}$ & $\begin{array}{c}\text { Pressure } \\
\text { difference } \\
\Delta P, \text { atm }\end{array}$ & $\begin{array}{c}\text { Hydraulic } \\
\text { efficiency, } \\
E, \%\end{array}$ & $\begin{array}{c}\text { Pollution } \\
\text { volume, } \\
\mathrm{m}^{3}\end{array}$ \\
\hline 1 & 0.01 & - & - & 0.01 & - & - & 0.01 & - & - \\
\hline $1^{\prime}$ & - & - & - & 0.1 & 44.99 & 10.2 & 0.3 & 12.72 & 36.5 \\
\hline 2 & 0.163 & 12.32 & 6.19 & 0.01 & 38.17 & 4.88 & 0.07 & 7.77 & 8.63 \\
\hline 3 & 0.328 & 61.83 & 10.54 & 0.06 & 100.0 & 0 & 0.22 & 50.49 & 12.73 \\
\hline $3^{\prime}$ & 0.143 & 92.78 & 0 & 0.12 & 96.54 & 0 & 0.14 & 95.74 & 0 \\
\hline 4 & 0.509 & 90.75 & 2.79 & 0.19 & 94.22 & 1.89 & 0.32 & 84.7 & 4.67 \\
\hline 5 & 0.351 & 90.09 & 1.5 & 0.13 & 98.85 & 0 & 0.35 & 83.89 & 1.74 \\
\hline 6 & 0.68 & - & - & 0.18 & - & - & 0.21 & - & - \\
\hline
\end{tabular}

\section{Conclusions}

1. According to the results of studies of the major gas gathering main, accumulation of the liquid phase in the «upstream sections» is noted. Accumulation of the liquid phase in the interval from the «valve 20a» to the «valve 32» (to increase in relief), which causes a decrease in the hydraulic efficiency coefficient is clearly observed. When analyzing the route profile after the «valve 32», it is observed that there is an increase in the hydraulic efficiency coefficient with a decrease in relief towards the «valve 99». The minimum accumulation of the liquid phase is also recorded. But it is established that the liquid accumulated at the interval «valve 20a» - «valve 32», reaching above-critical values, gas stream and favorable relief flows to the ChBCS inlet (separation equipment).

2. The operational factors and seasonal periods, which are most favorable for pollution formation, as well as local places of the pipeline gas gathering system that are most prone to pollution accumulation, are determined. In particular, it is shown that accumulation of the liquid phase in the field gas pipeline negatively affects not only the hydraulic efficiency and capacity, but also leads to the formation of an aggressive (corrosive) medium, which constantly contacts the inner surface of the pipeline and reduces the period of its trouble-free operation. It is proved that the liquid phase is accumulated in the pipeline due to changes in the thermobaric phase equilibrium conditions during gas transportation after preliminary gas treatment (from GTP) to compressor stations and group stations of in-depth treatment. The liquid accumulated in the pipeline consists of highly mineralized formation water and hydrocarbon condensate with a significant content of $\mathrm{CO}_{2}$ (carbon dioxide), $\mathrm{H}_{2} \mathrm{~S}$ (hydrogen sulfide), etc. Accordingly, in the accumulation of the liquid phase in the field gas pipeline section, taking into account the liquid corrosiveness, there are processes that lead to the pipeline wall corrosion, which in turn can lead to failure of the gas gathering and transportation system. This gives grounds:

- to note the importance of the analysis of the hydraulic efficiency of the system;

- to prevent excess pressure loss and hydrate formation processes;

- to neutralize the effect of corrosion processes on pipeline walls by developing the gathering and transportation system pigging measures.

3. Implementation of measures for liquid removal from the gas pipeline, which involves liquid drainage from the gas gathering main by installing an additional pipeline and using a specialized pigging device, allows carrying out drainage works without stopping the gas pipeline operation. It is shown that an integrated approach to the implementation of measures to improve the efficiency of the gas transportation system is effective:

- replacement of outdated and obsolete equipment of gas treatment plants, namely, screens (before the gas supply to the major gas gathering main on the interval «valve 20a»«valve $32 »)$;

- development of the schedule of periodic liquid drainage from the gas gathering main;

- determination of expediency of equipping the pipeline with start-up and receiving chambers for periodic gas pipeline cleaning from the residual liquid;

- installation of an expansion chamber on the investigated facility (at the Chervonodonetska BCS inlet) to prevent «breakaway emissions» of the liquid phase to the major processing equipment and the inlet of compressor units.

\section{References}

1. Truboprovidnyi transport hazu / Kovalko M. P., Hrudz V. Ya., Mykhalkiv V. B. et. al.; M. P. Kovalko (Ed.). Kyiv: Ahentstvo z ratsionalnoho vykorystannia enerhiyi ta ekolohiyi, 2002. $600 \mathrm{p}$.

2. Odishariya G. E. Gidravlicheskiy raschet rel'efnyh truboprovodov pri neznachitel'nom soderzhanii zhidkosti v potoke gaza // Gazovaya promyshlennost'. 1976. P. 42-43.

3. Zaycev Yu. V. Vliyanie haraktera gazozhidkostnogo potoka na effektivnost' ingibitornoy zashchity // Gazovaya promyshlennost'. 1978. Issue 2. P. 17-19.

4. Muhin V. E. Strukturnye formy techeniya gazozhidkostnyh smesey v trubah // Gazovoe delo. 1971. Issue 1. P. 13-15. 
5. Goldberg V., Mc Kee F. Model Predicts Liquid Accumulation Severe Terrain Induced Slugging for Two-Phase Lines // Oil\&Gas Journal. 1985.

6. Vyznachennia obiemu vidkladiv u diuchomu hazoprovodi ta yoho hidravlichnoi efektyvnosti / Kaptsov I. I., Bratakh M. I., Vynnyk S. M. et. al. // Problemy rozvytku hazovoi promyslovosti Ukrainy. 2001. P. 95-99.

7. Sposib kontroliu utvorennia hidrativ u hazoprovodi: Pat. No. 49764 UA. 6F17D3/00 / Vecherik R. L., Rudnyk A. A., Kotok V. B., Tkach O. I., Bantiukov Ye. M., Vynohradets S. O. et. al. No. 2002064609; declareted: 05.06.2002; published: 16.09.2002, Bul. No. 9.

8. Sposib kontroliu utvorennia hidrativ u hazoprovodi: Pat. No. 49762 UA. 6F17D3/00 / Chelombitko H. O., Volchkov I. I., Khaietskyi Yu. B., Kotok V. B., Bantiukov Ye. M., Dolhopolov S. H. et. al. No.2002064607; declareted: 05.06.2002, published: 16.09.2002, Bul. No. 9.

9. Bruk V. A., Hordiyenko I. A., Dutchak I. O. Do pytannia zapobihannia hidratoutvorennia v mahistralnykh hazoprovodakh // Pytannia rozvytku hazovoi promyslovosti Ukrainy. 2002. P. 150-153.

10. Bruk V. A. Sposob opredeleniya zagryaznennosti magistral'nogo gazoprovoda: Pat. SSSR No. 1247624. declareted: 19.02.1985; published: 30.07.1986, Bul. No. 28.

11. Darin L. G. Natural gas quality workshop. Session 2 // Effects of Poor Gas Quality and Causes of Sample Distortion. An SGAnetwork Web Conference. 2010.

12. Sposib kontroliu hidravlichnoho stanu mahistralnoho hazoprovodu: Pat. No. 34697 UA / Rudnik A. A. et. al. declareted: 01.04.1999; published: 15.03.2001, Bul. No. 2.

13. Bruk V. A. Vyznachennia rezhymiv roboty ta hidravlichnoi efektyvnosti hazoprovodu u vypadku neizotermichnykh techiyi // Pytannia rozvytku hazovoi promyslovosti Ukrainy. 2002. P. 154-158.

14. SOU 09.1-30019775-246:2015. Metodyka vyznachennia hidravlichnoho stanu hazoprovodiv systemy zboru i transportuvannia hazu z rodovyshch PAT «Ukrhazvydobuvannia». UkrNDIhaz, 2015. 43 p.

15. Pal'chikov V. P., Maslov V. M., Luchanskiy V. E. Beskontaktnyy sposob indikacii urovnya zhidkih otlozheniy v gazoprovodnyh sistemah // Peredovoy proizvodstvennyy i nauchno-tekhnicheskiy opyt, rekomenduemiy dlya vnedreniya v gazovoy promyshlennosti. 1989. Issue 2. P. 48-52.

16. Robert J., Purinton Jr. Cleaning pipeline interior with gelled pig: Pat. No. US4473408A. No. 4,473,408; declareted: 12.01.1982; published: 25.09.1984.

17. Moshfeghian M., Johannes A. H., Maddox R. N. Thermodynamic Properties are Important in Predicting Pipeline Operations Accurately // Oil\&Gas Journal. 2002. Vol. 100, Issue 5. P. 56-62.

18. Norris H. L., Rydahl A. Simulation reveals conditions for onshore arctic gas-condensate pipeline // Oil\&Gas Journal. 2003.

19. Mokhatab S. Correlation predicts pressure drop in gas-condensate pipelines // Oil\&Gas Journal. 2002. P. 66-67.

20. VNTP 51-1-85. Obshchesoyuznye normy tekhnologicheskogo proektirovaniya. Magistral'nye truboprovody. Chast' 1. Gazoprovody. Moscow, 1986.

21. Bratakh M. I., Zaid Khalil Ibrakhim, Hrebeniuk S. D. Vplyv hidravlichnoho stanu systemy promyslovykh hazoprovodiv na rezhym roboty obiektiv hazovydobuvnoho kompleksu // Intehrovani tekhnolohiyi ta enerhozberezhennia. 2015. Issue 1. P. $22-26$.

22. Abdumula, M. F. Crude Oil Pipelines Inspection // Technology of Oil and Gas Forum and Exhibition. 2004.

23. Horin P. V., Tymkiv D. F., Holubenko V. P. Systematyzatsiya metodiv ochystky hazozbirnykh merezh dlia transportuvannia hazu zrilykh rodovyshch // Komunalne hospodarstvo mist. Seriya: Tekhnichni nauky ta arkhitektura. 2017. Isssue 134. P. 52-57.

24. Abdumula M. F. Heavy Hydrocarbon Testing Methodology // The Micro CAD International Scientific Conference Hungary Miskolc. 2004.

25. Abdumula M. F. Influence of Paraffin Flocculation in Crude Oil Tran sported Pipelines with Economic View of Pigging Process // 1st International Conference and Exhibition in Oil Field Chemicals. 2003.

26. Abdumula M. F. Wax Precipitation in Crude Oil Tran sporting Pipelines // The Micro CAD International Scientific Conference Hungary - Miskolc. 2004.

27. Al-Yaari M. Paraffin Wax Deposition: Mitigation and Removal Techniques // SPE Saudi Arabia section Young Professionals Technical Symposium. 2011. doi: 10.2118/155412-ms

28. Gupta A., Sircar A. Introduction to Pigging \& a Case Study on Pigging of an Onshore Crude Oil Trunkline // IJLTEMAS. 2016. Vol. V, Issue II. P. 18-25. URL: https://www.researchgate.net/publication/307583466_Introduction_to_Pigging_a_Case_Study_ on_Pigging_of_an_Onshore_Crude_Oil_Trunkline

29. Uhlig's Corrosion Handbook / R. Winston Revie (Ed.). 3nd ed. Wiley, 2011. 1296 p.

30. Zvit pro naukovo-doslidnu robotu «Monitorynh ta analiz hidravlichnoho stanu systemy hazoprovodiv, po yakykh transportuietsia haz z rodovyshch HPU «Shebelynkahazvydobuvannia» / Shymanovskyi R. V., Stetsiuk S. M., Bratakh M. I., Koliadenko V. A. Kharkiv, 2017. 193 p. 